\title{
ENTRE PRÉDIOS ENVIDRAÇADOS, UMA CRUZ ESLAVA: ucranianos, bens culturais e a cidade
}

\author{
Paulo Augusto Tamanini*
}

\section{Resumo}

Este artigo preocupa-se em tecer alguns apontamentos sobre o local de estabelecimento dos imigrantes ortodoxos ucranianos na cidade de Curitiba e verificar quais as estratégias adotadas, no intuito de preservar os bens culturais étnicos, durante o processo de modificação do espaço trazido pela urbanização da Avenida Cândido Hartmann (que até 1978 se chamava Vila dos Ucraínos). Para buscar as informações que dão suporte às análises que contemplem os temas 'bens culturais e a cidade', depoimentos tomados de imigrantes que moravam no bairro, atentam para perceber a relação dialética entre o lugar e o conjunto de crenças e práticas culturais do grupo. Se de um lado a urbanidade tende a homogeneizar lugares que se criam específicos, por outro, quando há interesse, reforça as identificações étnicas em espaços apropriados.

Palavras-chave: Igreja Ortodoxa. Bens culturais. Cidade.

\section{Historiografia e as religiosidades urbanas}

A pertinência de certos temas ou problemas inerentes aos assuntos do sagrado em meio urbano tem aproximado saberes e evidenciado fontes importantes que emergem da obscuridade onde estavam relegadas, até as últimas décadas do século XX. Neste rastro, os pequenos e grandes eventos, a vida privada, dizeres e escritos pastorais de clérigos, nascimento de pequenas comunidades religiosas e sua atuação pastoral nas cidades destacamse no regime atual de se fazer história à medida que se revelam cheias de sentidos e significados, próprios para a percepção do mundo na qual homens e mulheres também se relacionam com o absoluto, com o transcendente, mesmo que inseridos no emaranhado de prédios e praças planejadas, típicas das cidades modernas. 
Sob um novo olhar, a emergência da religião e das religiosidades na historiografia tem sublinhado que às ciências humanas interessa compreender o homem do campo e/ou da cidade em sua totalidade, inclusive em sua dimensão mística. No regime moderno de historicidade, o homem deixa de ser analisado somente pelo crivo da razão, para ser percebido também em suas subjetividades e em seus pertencimentos, abrindo ao pesquisador novas maneiras de compreendê-lo.

No campo de estudos das religiões, torna-se crucial entender não somente que a diversidade religiosa existe, mas que ela possui vários sentidos e definições; e o lugar onde estes conceitos são pensados influencia nas posturas que as pessoas têm em relação à crença do outro. Assim, os conceitos 'religião’ e ‘igreja' são compreendidos com mais largueza, soltando as amarras que os unia à concepção monoteísta judaico-cristã, substituindo-a por uma definição polissêmica. Deste modo, amplia-se a possibilidade de se compreender os fenômenos religiosos e os vínculos a certas instituições a partir de conceitos revistos, o que exige reformulações dos postulados teóricos que já não mais conseguem responder às problemáticas levantadas pela atual historiografia. O que interessa não é mais saber em que deus se crê, mas perceber a experiência religiosa decorrente da profissão de uma determinada fé.

Gravitam em torno destas abordagens não só as igrejas majoritariamente presentes no Brasil, mas aquelas que são vistas como minorias e de pouca expressão. As inúmeras pesquisas, fontes, GTs, Simpósios Temáticos têm mostrado justamente que novas expressões de fé informam sobre a cultura, sobre sistematização de crenças e que religião e religiosidades não significam necessariamente teologia, mas sistemas complexos de saber e de poder - que se querem divinos - e que se revelam através de uma linguagem específica. O lugar onde se expressa e se materializa a fé também é uma forma de linguagem, de comunicação que informa algumas especificidades do sagrado em meio urbano.

Assim, importante contribuição dão os pesquisadores à historiografia religiosa ao precisar que a multiplicidade de crenças influencia na forma de se teorizar sobre o campo religioso. Seguindo este rastro, atenta-se para questões em torno da lógica e funcionamento da produção de crenças, o que faz acelerar e provocar o que Bourdieu chamou de 'conversão do olhar' ou 'ruptura epistemológica' (BOURDIEU, 1989:39). Fortemente estudados são os conceitos de ‘identidade religiosa’ e ‘sujeito religioso’, uma vez que pessoas não se sentem mais obrigadas a permanecer somente em uma igreja, transitando entre tantas opções. Atualmente, em meio urbano, a escolha e o compromisso de assumir determinada vinculação religiosa e o consequente sentimento de pertença não podem ser mais garantidos. 
A integração e a legitimação de motes que abordem expressões religiosas marginais tornam-se um intrigante desafio para os pesquisadores, uma vez que ser cristão em um país multicultural não significa necessariamente ser católico romano ou evangélico. Nas brechas do mosaico religioso do Brasil estão as igrejas ortodoxas - estabelecidas junto às comunidades imigrantes desde o final do Império - com seus templos em estilo bizantino-eslavo, seus ritos e símbolos, com suas estruturas doutrinárias e disciplinares específicas.

Como estas igrejas não podem ser entendidas como realidades estanques, mas que se deslocam de seu lugar simbólico e interagem com o contexto cultural onde se situam, investigá-las nesta permanente interação oportuniza não só conhecê-las em suas contínuas recomposições e rupturas, mas na maneira como se anunciam, se apresentam e se identificam. Se o sujeito tece relações, cria círculos de saberes, participa e posiciona-se diante das refrações da vida pública e privada, os membros das igrejas ortodoxas, ao se inserirem em meio à sociedade plural, de certo modo anunciavam por suas condutas um pertencimento religioso diferente dos demais, o que por si só desbanca a pretensão de se legitimar a presença de apenas um único ramo do cristianismo no país, qual seja, o latino: romano, protestante , (neo) pentecostais, com suas possíveis ramificações. Mesclado a tantas igrejas latinas, o rito bizantino contracena em espaços próprios, no interior das poucas igrejas e catedrais ortodoxas erigidas pelos imigrantes europeus e eslavos desde o final do século XIX.

Contudo, se é no interior dos templos que o sentimento de pertença se revigora, é justamente fora deles que ele é testado. Se ao chegarem ao Brasil, o sentimento de pertença e o cuidado de se preservar ritos, condutas, posturas eram mais asseverados, com a modernidade e vivendo em espaços urbanos, também os ortodoxos ucranianos procuraram reelaborar performances diferenciadas na profissão e vivência da fé. Observa-se que também em comunidades ortodoxas gravitam maneiras heterodoxas de se professar a fé bizantina. Hoje, como os da igreja católica, fieis das igrejas ortodoxas relativizam os ditames que da hierarquia brotam, questionando sua aplicabilidade e funcionalidade ante a diversificada oferta cultural que se cruza em espaços da cidade. Diante de tais ressalvas, a desinstitucionalização aos poucos se impõe, destronando as vozes autorizadas da hierarquia, substituindo-a, ainda que parcialmente, pela individualização. Obedece-se, ou melhor, adéqua-se a determinadas normas de cunho religioso na medida em que estas não obstaculizem o viver pluriforme do urbano de onde emanam formas mais brandas de se viver o cotidiano.

Assim, este artigo preocupa-se em tecer alguns apontamentos sobre o lugar em que os imigrantes ucranianos que professavam a fé cristã de vertente ortodoxa se estabeleceram. A 
vila dos ucraínos, com a urbanização e ao sofrer intervenção do poder público, de um local com peculiaridade rural, transformou-se em um centro de referência do desenvolvimento de Curitiba, ganhando inclusive outro nome: bairro Bigorrilho. Investigo, então, em que medida a remodelação do locus de estabelecimento motivou as famílias e o poder público local a preservarem os bens culturais da etnia, lhe dando visibilidade e materialidade em meio aos espaços da urbe. Para buscar as informações que dão suporte às análises que contemplem os temas 'bens culturais e a cidade', depoimentos tomados de imigrantes que moravam no bairro atentam para perceber a relação dialética entre o lugar e o conjunto de crenças e práticas culturais do grupo. Se de um lado a urbanidade tende a homogeneizar lugares que se criam específicos, por outro, quando há interesse, reforça as identificações étnicas nos espaços apropriados.

\section{Entre prédios envidraçados, uma cruz eslava}

Foi no período do pós Segunda Guerra que muitos imigrantes europeus chegaram à cidade de Curitiba, movidos pela oferta de mão de obra específica às áreas da construção civil e indústria madeireira, tão propagandeada pela política de migração do governo de Bento Munhoz da Rocha Neto, que fomentava a vinda de contingentes europeus à capital paranaense (LACERDA, 1951, p.02). Nas décadas de 1950 e 1960, a cidade ficou marcada não só pelos grandes investimentos do governo federal e estadual, que realizaram obras de grande envergadura em urbanismo, concretizando muitos dos desejos e anseios de uma classe abastada que esperava pela modernização da capital. A construção do Centro Cívico, Biblioteca Pública do Paraná, Teatro Guaíra e dos edifícios Dom Pedro I e Dom Pedro II, da Universidade Federal do Paraná - em torno dos quais gravitava a vida política, burocrática e cultural-, trouxe o crescimento populacional formada pelos intelectuais, advogados, comerciantes e industriais, como também aqueles que precisavam trabalhar, sem a devida qualificação (LACERDA, 1951, p.04). O fervilhar do progresso urbano trouxe para Curitiba não só a circulação da técnica e dos saberes de um futuro centro metropolitano, como a multiplicidade étnica marcada pelos variados fenótipos, crenças e idiomas que aprenderam (forçosamente ou não) a compartilhar o mesmo espaço territorial.

Assim, se no centro de Curitiba as obras aconteciam em ritmo acelerado, nas vilas mais afastadas os imigrantes preservavam as práticas rurais das cidades do interior, no ritmo a que estavam acostumados. Às margens dos grandes canteiros de obras, imigrantes italianos, 
espanhóis, alemães e ucranianos dedicavam-se às atividades agropecuárias fornecendo de porta em porta ou nas feiras livres do centro da cidade o que as donas de casa produziam.

Se a harmonia é o resultado da integração de múltiplos vetores individuais que convergem para um ponto formando um todo, cada uma das partes, no entanto, individualmente analisada, revela-se em sua complexidade. A capital do Paraná parecia então ser o palco no qual se desenvolviam cenas coletivas com tanta desenvoltura e maestria, que o todo citadino desfibrilava-se em um visível mosaico étnico: imigrantes vindos de diferentes países europeus ( e outros, de estados brasileiros) testemunhavam o erguimento de uma outra Curitiba. Chegaram de diferentes lugares, em geral de grandes centros, e traziam consigo referências e valores assimilados em seus locais de origem. Com o crescimento da cidade e a consequente heterogeneização de sua população, novos mundos sociais coexistiam e disputavam territorialidades, deixando suas referências e fontes para uma possível identificação étnica no complexo mapeamento do local que os acolheu.

Ao pesquisar os bairros que margeiam a área central de Curitiba, observa-se que os imigrantes marcaram o lugar de recepção de tal forma, com elementos identitários de ordem familiar, comunal e religiosa que, ainda hoje, identifica-se facilmente onde estavam aglomerados: no centro, os imigrantes árabes; os italianos, no bairro Santa Felicidade; os espanhóis, em Osório; os ucranianos, no Bigorrilho etc. Nestes locais, até a década de 1970, a igreja tinha um lugar de predominância e era em seu entorno que as casas eram construídas. A vida de muitas famílias prosseguia, sendo dirigida, muitas vezes, pelos preceitos religiosos e costumes étnicos.

Se o bairro é a soma de ruas, de avenidas, onde casas e prédios são perfilados e numerados, a geografia do lugar - produto da imaginação e racionalização humanas-, rege-se pela duração de uma intencionalidade. Se algumas ruas são pensadas e posteriormente projetadas a partir de uma ideia, outras ganharam a benevolência dos arquitetos e paisagistas, após algum tempo da feitura inicial: bairros que nasceram da necessidade de morar ganharam contornos urbanos após uma readequação e conformação dentro do planejamento e urbanização. Por vezes, coexistem lugares projetados naqueles que tiveram sua gênese na indigência: a vila dos ucraínos, por exemplo, formou-se pela aglomeração de casas que se estendeu até os lugares mais afastados da igreja, que é o centro polarizador da maioria das comunidades imigrantes. No início, as casas obedeciam ao serpentear das vielas que uniam as famílias. Com o crescimento e desenvolvimento da cidade de Curitiba, as autoridades municipais intervieram na geografia da vila, promovendo-a a avenida e rebatizando-a com o 
nome de Cândido Hartmann (de origem alemã), o que poderia impossibilitar identificar no futuro que aquele espaço era originalmente composto por famílias ucranianas.

Assim, a feitura da avenida reinventou os contornos e os acessos à custa de desapropriações e do afastamento de muitas famílias imigrantes para regiões mais afastadas. Por outro lado, há exemplos que a iniciativa de egresso partiu dos próprios imigrantes e descendentes já que não fazia mais sentido permanecer em locais onde os laços de familiaridade e proximidade foram amainados. Percebe-se que o tracejar da avenida não só retirou as famílias como atenuou as motivações de lá permanecer. A funcionalidade e o utilizável desbancaram subjetividades e negligenciaram memórias da etnia que estavam instaladas em muitas moradias.

No bairro dos ucraínos, desde sua formação no final do século XIX, as casas foram construídas próximas uma das outras, não só por aparentar certa unidade entre o grupo, mas como estratégia de proteção e conservação dos bens culturais. A este respeito a historiadora Giralda Seyferth (1990, p.65), ao falar dos imigrantes em geral, nota que “a imigração no contexto urbano tem como característica principal a aglutinação dos imigrantes de mesma origem em torno de interesses comuns e estimula a solidariedade para enfrentar situações novas”.

Segundo Dom Jeremias Ferens (2010), arcebispo ortodoxo ucraniano, ainda na década de 1970, “as pessoas se visitavam frequentemente, conversavam na língua materna, trocavam receitas, combinavam cerimônias de casamento e batizado com o sacerdote que também morava com eles”. Os saberes étnicos e religiosos circulavam e se intercambiavam no cotidiano, parecendo natural expressar sua ucraneidade nos muitos afazeres do dia a dia. Segundo o arcebispo, "as crianças brincavam na rua, tocavam o gado de um lado para o outro”, sem muito se preocupar com a circulação de estranhos. Para Ferens (2010), “as noites pareciam mais escuras, ouviam-se os grilos e as cigarras executarem suas sinfonias e, pela manhã, em cima das árvores, o majestoso cantarolar dos pássaros anunciando um novo dia”. A lembrança do prelado ainda o faz ouvir o cantar dos pássaros que exibiam seus gracejos ritmados sobre os ramos das árvores, mas que hoje estão encarcerados em lindas e modernas gaiolas dependuradas em varandas dos apartamentos. Para o arcebispo, "não é mais o mesmo som, porque passarinhos em cativeiro não cantam suas alegrias, mas lamentam sua falta de liberdade”. A forma poética, leve e sedutora de descrever as lembranças pelo arcebispo parece fazê-lo acreditar na existência única de um passado melhor do que o presente. Se na memória de Dom Jeremias os grilos, as cigarras, os pássaros e a pouca luminosidade da noite ainda pululam em sua memória por puro arrebatamento do pretérito, há que se conceder um 
tributo às impressões congeladas da cultura étnico-religiosa que ainda o impressionam e tiram do adormecimento os desejos da antiga estrada por onde as crianças tocavam o gado e executavam suas traquinagens e peraltices.

Pelo depoimento acima, verifica-se que houve certo esforço para apreender as novas maneiras de se viver no bairro repaginado. Os bens culturais expostos em cenários urbanos fundem-se aos outros contextos da cidade, intervindo na maneira de preservar o que se julga característico da etnia. Usando uma expressão de Baudelaire (2007), o ucraniano no bairro moderno do Bigorrilho é um "pintor de costumes" que seleciona e que recolhe, ao final do dia, as imagens a partir das quais tenta relembrar sua ucraneidade.

Por a cidade não contar seu passado, simplesmente porque o contém tais quais as linhas das mãos (CALVINO, 1990, p.6), por mais que se maquiem os lugares, os ângulos das ruas, "as floreiras nas janelas, os pássaros presos em gaiolas expostas nas varandas, as cores dos gatos que desfilam entre as casas e o latidos dos muitos cães do bairro", persistem nas lembranças de quem assim as viveu e continua desejando aquele lugar (FERENS, 2010).

O desejo do prelado em presentificar o que já experenciou não se reduzia apenas à recordação, revelava-se como símbolo que o transportava para outros anseios. Embora seu olhar esteja voltado para trás, é no presente que ele e muitos dos descendentes ucranianos reaprendem a lidar com as novas sensações trazidas pela nova avenida chamada Cândido Hartmann. A avenida dos ucraínos ou a avenida Cândido Hartmann, mesmo que se situem no mesmo lugar do mapa, para alguns tratam-se de territorialidades diferentes. A prosperidade que se exibe ao longo de suas margens não acalenta a saudade da época em que tudo parecia rotineiro, aprazível nas lembranças, mas que pode ser contestável na empiria.

Também o pertencimento religioso ou a filiação eclesial dos ortodoxos é um dado fundamental a ser considerado dentro da dinâmica da representação étnica articulada ao espaço social urbano, ante a emergência das relações alinhavadas entre costumes e lugares. Em seus discursos, para muitos imigrantes ser 'ortodoxo' não se restringia em seguir fielmente os preceitos religiosos; a inflexibilidade adentrava nas posturas e maneiras de se encarar a vida e fixar-se em poucos ou em único lugar.

Se muitas casas foram destronadas, a igreja permaneceu em seu lugar como uma referência do passado e da comunidade imaginada. Como as mudanças e alterações trazem consigo o consequente esquecimento (parcial ou total) do estágio anterior, a igreja, que teimosamente resiste às intervenções e ao aviltamento do bairro que se cria ucraniano, tornou-se memória materializada de uma cultura que evoca presença. 
A igreja é um edifício que fala por si. Sua forma arquitetônica em estilo eslavo anuncia um pertencimento e o lugar que ocupa dentro da organização do bairro indica sua função. O templo, independentemente de a que selo religioso esteja vinculado, é o lugar onde o sagrado tem sua primazia e através do qual os que o reconhecem desta forma se identificam. Assim, a igreja é capaz de regular o comportamento dos presentes e manter algo de específico da etnia; não porta só valores morais e de fé, mas parece ter eficácia e autoridade no grupo. Por isso, a catedral ortodoxa de São Demétrio registra uma identidade em meio a tantas outras identidades do bairro. Por ser também o invólucro de símbolos, aquele lugar de culto traz consigo também as memórias, as recordações e as representações, estabelecendo uma relação de afinidade, servindo de constante evocação da memória pela repetição, para não sumir, desaparecer, desfazer-se e ser esquecida. Por sua vez, “a memória também é redundante: repete seus símbolos, para poder existir” (CALVINO, 1990, p.11), bastando espaço para eclodir.

Nas décadas de 1970 e 1980, na Cândido Hartmann, aos poucos, antigas moradias foram substituídas por casas do comércio que por sua vez foram repaginadas, ganhando marcas do progresso. As geografias desiguais foram nivelando-se pelos ditames de uma época marcada pela intensa efervescência da criatividade urbana. O banal e o marginal metamorfoseiam-se em lugares de distinção e de sobriedade, demonstrando que lugares são frágeis, vítimas das práticas arquitetônicas e das “opções de um urbanismo servil que visa o lucro em detrimento da cultura” (ANSAY, SCHOONBRODT, 1989, p.16).

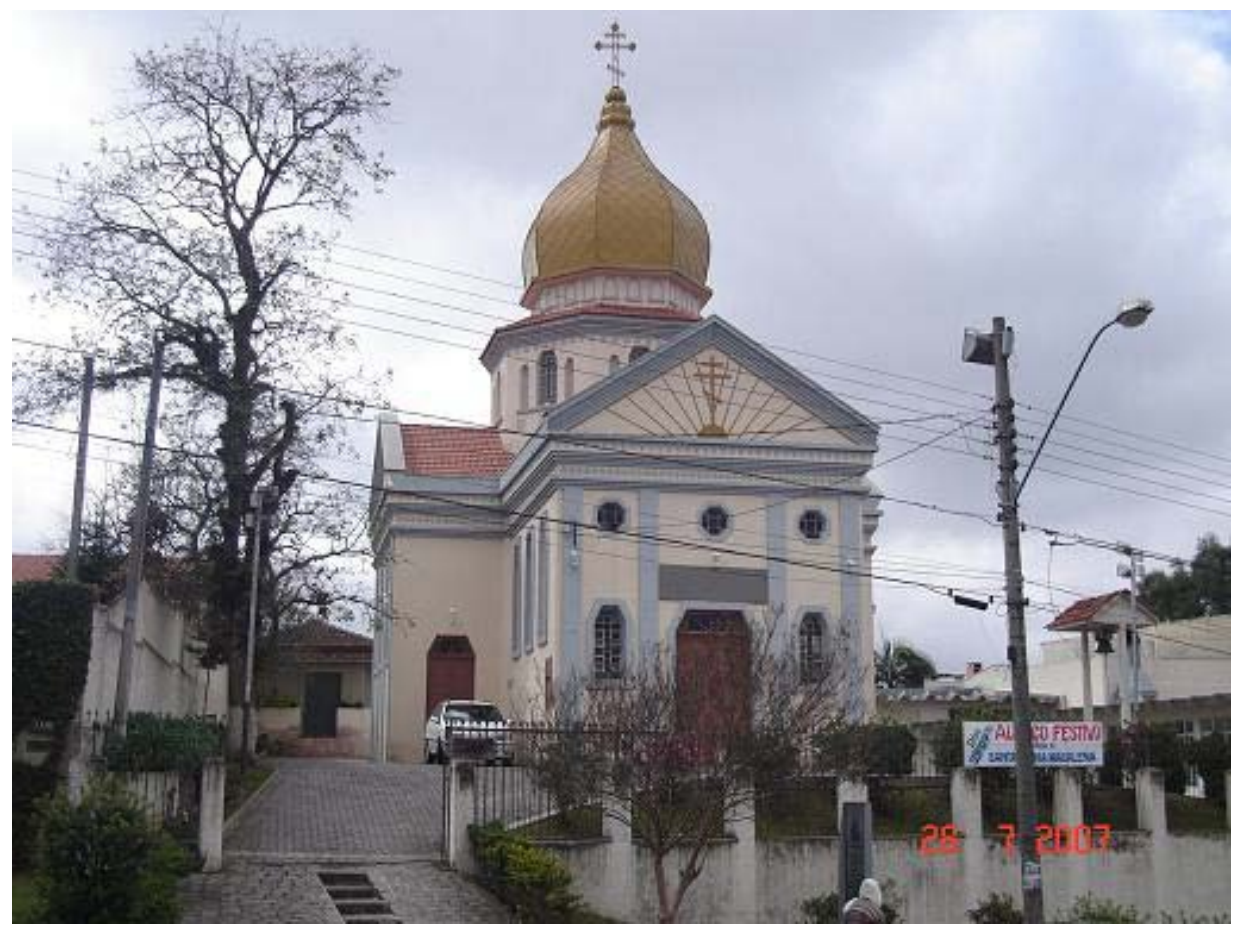

Figura 1 Catedral Ortodoxa São Demétrio. Acervo da Eparquia. Jul/2007. 
Em meio aos prédios da planejada Avenida Cândido Hartmann, na cidade de Curitiba, em frente à sofisticada academia Swimex Fitness \& Wellness, a catedral ortodoxa ucraniana se impõe com suas formas arquitetônicas específicas, fazendo lembrar aos transeuntes e clientes daquele empreendimento fisiculturista que o homem não se constitui só de matéria, mas por cultura, por valores, por subjetividades. A atual catedral dos ucranianos ortodoxos começou a ser construída em 1955, com a aquisição de dois terrenos de 22x50 m cada. O esquadrejamento e a preparação do terreno ainda estavam em andamento quando, em 13 de maio de 1956, foi celebrado o primeiro ofício religioso da bênção da obra e, em 04 de novembro do mesmo ano, foi feita a bênção da pedra fundamental. A obra foi concluída em 1960, graças à ajuda dos fiéis e de empresas cujos dirigentes ou sócios comungavam da mesma crença e pertencimento religioso. O primeiro reitor paroquial foi Pe. Pedro Dobrianskyj, que vinha de São Paulo para atender a comunidade, permanecendo nesta função até 1964, quando do seu falecimento, e foi sucedido pelos sacerdotes Pe. Nicolau Stcherbak (1964-1967), Pe. Pedro Blachechen (1986-1989) e o então Pe. Jeremias Ferens, hoje, arcebispo, que iniciou seus trabalhos pastorais em $1989^{1}$.

A academia, no entanto foi inaugurada em 1998, quando a Avenida Cândido Hartmamn era referência de desenvolvimento comercial. Pelas paredes envidraçadas, os frequentadores da academia, vestidos com roupas apropriadas para o exercício físico intenso, se deparam diariamente com religiosos trajados com suas escuras batinas circulando por entre o complexo religioso formado pela igreja, salão de festas e residência episcopal. De um lado da avenida, jovens, em sua maioria, esculpem seus corpos a custas de exercícios em variados aparelhos modernos; do lado oposto, a preocupação pelo físico dá lugar à prática de piedade, feita em sua maioria por pessoas de meia-idade em busca do aprimoramento da alma. Duas visões de mundo convivem num mesmo espaço, separados apenas por uma avenida por onde circulam um intenso tráfego. Não é apenas uma avenida, é um lugar de coexistências, de cruzamento das correntes culturais, de visões de mundo, cuja materialidade se acomoda na dinâmica de relações próprias do urbano. Quadros de vida que se interpolam, fazem embaralhar o sagrado e o profano, enfatizando entre eles a ausência de linhas demarcatórias que poderiam estabelecer limites.

\footnotetext{
${ }^{1}$ Informativo Eparquial da catedral São Demétrio. Curitiba, 2006, p. 3-5.
} 


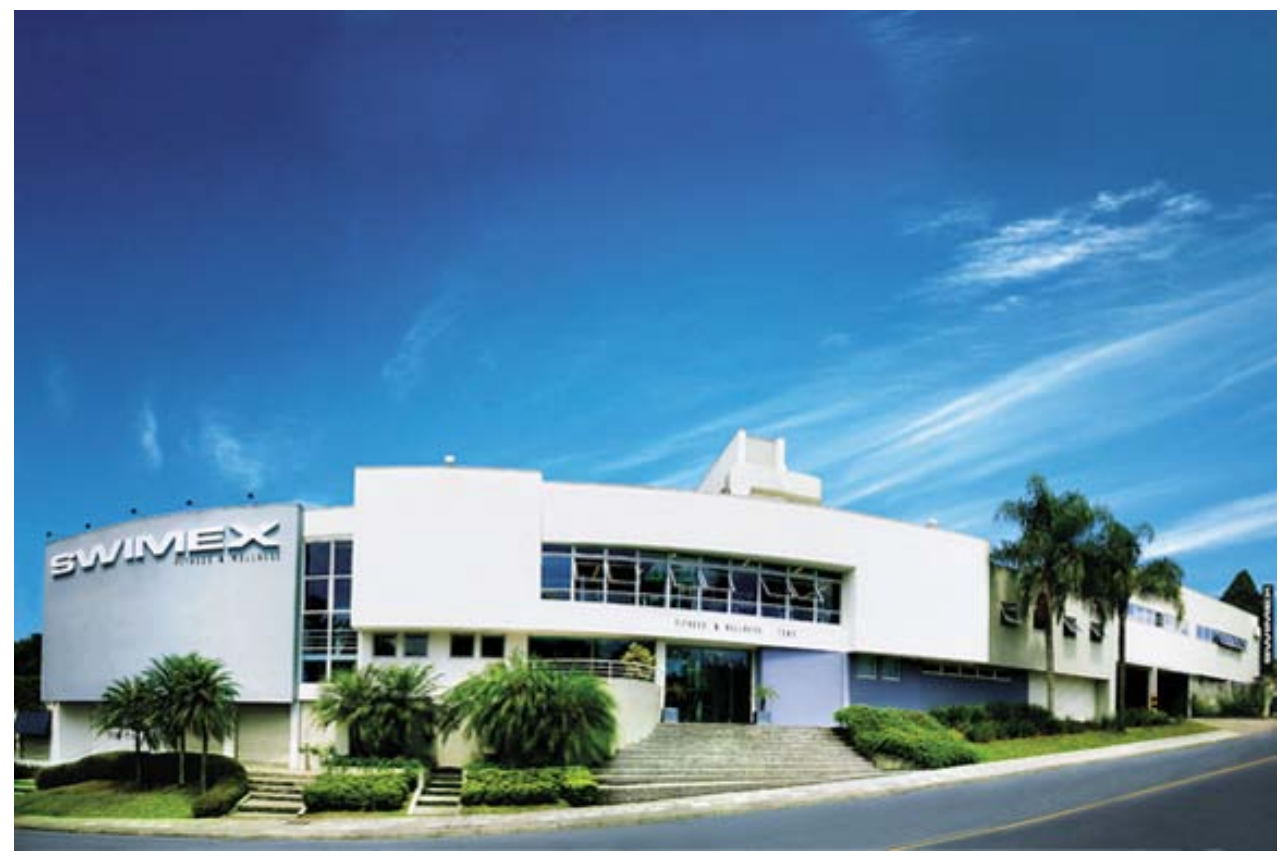

Figura 2 Academia Swimex. Foto de Divulgação. Març/2009

O complexo religioso todo murado não é obstáculo para aqueles que do andar superior da academia assistem de soslaio o que se passa no interior da igreja. Do outro lado, o mesmo não acontece: os vidros escurecidos permitem apenas enxergar nuances de pessoas que malham, que praticam lutas, que se embelezam. Talvez, nas cidades modernas, os muros sejam maneiras ultrapassadas de delimitar territórios e segredar o que nele está contido. Hoje, nas cidades verticalizadas, os vidros, o aço e sistemas de segurança - que se crêem eficientesproduzem nas pessoas da urbe uma sensação de segurança, cuja eficácia por vezes é contestada. De toda forma, sejam os religiosos que circulam de um lado da avenida, sejam os frequentadores da academia de outro, ambos se confrontam com realidades plurais, com mundos formados não apenas por aquilo que se conhece ou se quer conhecer, mas por mundos onde pululam as especificidades e as diversidades tão próprias do adensamento urbano, que exigem a reciprocidade de respeito.

Nesta esteira, Nestor Garcia Canclini (2008, p. 258) sugere que a urbanidade seja capaz de aliançar práticas culturais dessemelhantes até porque, segundo o autor, na modernidade nega-se a demarcação de territórios culturais, entrando em cena a hibridação. Surgida da criatividade individual e coletiva que reconverte e reinsere práticas culturais distintas, a hibridação facilita a circulação, troca e interação de novas maneiras de se encarar o diferente. Em espaços urbanos parece que as fronteiras são muito líquidas, porosas e pouco funcionais. 
O autor entende por hibridação "processos socioculturais nos quais estruturas ou práticas discretas, que existiam de forma separada, se combinam para gerar novas estruturas, objetos e práticas” (CANCLINI, 2008, p. 19). As práticas discretas que são encenadas em territórios separados sugerem a existência de fronteiras, de limites, de demarcações onde se constroem espaços adequados. É preciso observar se o campo de identificação religioso rasurava algumas condições de fronteiras entre grupos de interesse especiais. A partir desta concepção, é possível afirmar que os discursos que privilegiam a peculiaridade étnica ou religiosa de certo grupo agigantam possibilidades de sectarismos e intolerâncias, o que reflete em diversos signos de pertencimento. Se a percepção de si sedimenta olhares, possibilitando ou não os estranhamentos ou os reconhecimentos, é necessário perceber de que ucraniano estamos falando e como o pertencimento religioso e o local de estabelecimento interferiam nesta identificação .

Parece que a noção do híbrido nasce da crise de conceituar com precisão o resultado do encontro e da interpenetração de culturas dessemelhantes, num mesmo espaço, o que faz desencadear novas combinações e sínteses compartilhadas. Os ucranianos de Curitiba experienciavam o entrecruzamento de diferentes tempos históricos: tradição camponesa e práticas modernas do viver, fazendo-se presente em espaços e tempos contemporâneos. Embora Canclini (2008, p.283) assinale não haver forte oposição entre o urbano e as práticas culturais do mundo rural, os ucranianos ortodoxos ajustavam-se às exigências da cidade para poder encenar e demonstrar vínculos locais de afetividade, em novos cenários.

É preciso pontuar que os novos espaços forçaram os ucranianos a uma re-socialização, já que a urbanização do Bigorrilho trouxe novos moradores e/ou transeuntes com novos hábitos e novos comportamentos exigindo, em nome da acomodação e interação, um outro aprendizado. As transformações do lugar de recepção o tornaram um espaço estranho e que passava a ser analisado e mensurado tendo como referência o passado e o que se herdou dele. O panorama urbanístico implantado no bairro não só verticalizou as habitações como remodelou significativamente os modos de morar, de trabalhar, circular e viver. Além do alargamento da avenida e da construção de outras, o incremento dos serviços de abastecimento de água, esgoto e de iluminação pública proporcionou condições outras de vida social para imigrantes ucranianos acostumados a um espaço geográfico mais familiar, sem a heterogeneidade de tipos, sem aglomerações e tumultos.

Se “as palavras insuflam a vida na história”, como afirma Paul Thompson (1992, p.41), nem sempre significa que esta vida fosse a desejada por todos. Maria Olikéria (2010) relata, por exemplo, que “depois que as máquinas chegaram para alargar as estradas, a vida 
ficou mais agitada e o barulho nunca mais foi embora. Tempos bons eram aqueles onde se podia, em vez de barulho, ouvir os pássaros das árvores cantarem e, em vez de fumaça, respirar ar puro!” Maria em seu relato conta que sente saudades do ar que podia respirar quando as máquinas ainda não poluíam o ambiente. Naquela época, especifica Maria, as fumaças que subiam ao céu “era apenas das chaminés dos fogões a lenha”. Baseado no que diz Maria, é possível dizer que depois que caminhões, escavadeiras e máquinas de terraplanagem faziam parte do cotidiano, as fumaças saídas das chaminés se sentiam intrusas num céu que foi assenhoreado por outros gases.

Maria e outros ucranianos ao assistirem a urbanidade adentrar em seus territórios acionavam dispositivos para reagirem ao diferente. As máquinas trouxeram em seu bojo não só barulho como também afastou o caráter organizacional do lugar ao subtrair elementos que auxiliavam na identificação de uma comunidade rural a que estavam acostumados. Desde então, o entorno sociocultural (a rua, a viela, as árvores e as casas) passou a ser visto sob novos olhares e, às vezes, pela ótica do estranhamento. A mudança do lugar acarretou mudanças na maneira como pessoas se viam e como enxergavam os outros. Neste sentido, Sandra Pesavento (1999, p.48), referindo-se a Paris, compartilha com a ideia de que um "novo sentimento é inaugurado pela estranheza de se viver, representar, entender e sentir em locais transformados, fazendo com que nas pessoas ecloda "uma nova postura diante do fenômeno urbano".

Se os imigrantes desejavam a estagnação do lugar, o poder público, contudo, almejava uma concepção moderna de se viver no centro de Curitiba - que se espraiava para os bairrosbaseado na diversificação, mobilização e circulação dos bens (materiais e culturais), onde a vida pudesse acontecer de maneira civilizada e racional. Os habitantes (imigrantes ou não) desses espaços remodelados deveriam caracterizar-se em contraposição ao habitante do campo e do meio rural considerando-se sujeitos do urbano, o que de certa forma fez brotar em alguns imigrantes o sentimento de estranheza e não mais de identificação. A mudança se dava a passos tão largos que muitos não acompanharam.

A nova Avenida Cândido Hartmann estava sendo preparada para a modernidade à medida que arquitetava terrenos essenciais à vida citadina, mesclada pelo progresso, mas também pela desordem. Territorialidades do silêncio e habitat exclusivo dos ucranianos foram se perdendo, o que se constatava pela ausência da língua eslava dos diálogos dos transeuntes e pelos roncos dos motores ligados que compunham a trilha sonora dos cenários que retratavam um mundo em obras. Era preciso então buscar outras paragens de identificação! 


\section{A realocação dos espaços de identificação ucraniana em curitiba}

Quer imigrante ou não, as pessoas existem, vivem e se socializam dentro de uma esfera circunscrita chamada lugar, onde é possível flagrar os descaminhos ou trajetos nem sempre lineares das relações entre pessoas e cenários e descobrir conexões possíveis. Se em determinado tempo foi preciso deslocar os ucranianos do seu habitat considerado estratégico para o progresso da cidade, por outro era preciso conservar as marcas de pertencimento, como tributo de uma presença. Em meio às celebrações da urbanidade e do progresso era importante edificar lugares de memória que pudessem resguardar do passado as referências de uma cidade que se superou e que se desvencilhou dos ares provincianos. Se por um lado era preciso celebrar o novo, por outro era prudente reservar algum canto da cidade onde se pudesse rememorar o passado. Se a urbanidade engoliu os aspectos provincianos de um lugar tido por estratégico para o progresso urbano, era preciso regurgitá-lo em outras paragens onde o ucraniano pudesse rememorar. No entanto, a construção dos espaços de lazer, de parques e de praças temáticas estão dentro de um plano macro de urbanização e que deveriam obedecer a lógica do crescimento entrelaçado a um frágil sentimento de preservação, onde a subjetividade deveria se envergar ante o raciocínio do progresso.

Toda paisagem urbana é justificada pela satisfação das necessidades do homem que precisa movimentar-se física e intelectualmente. Assim, marcos fixados e símbolos de pertencimento elaboram e priorizam um uso cenográfico onde é possível extrair e explicar sentidos. Se o lugar não é um dado neutro (SANTOS, 2000, p.80) por informar e revelar identidades não só físicas, mas culturais, a invenção de paisagens que lembrassem a presença dos imigrantes ucranianos avisava que traços daquela cultura também faziam parte do cenário estético da cidade. E isto era recomendável, em nome da cultura, ser relembrado, até porque uma cidade que não tem história e raízes não pode ser explicada. Percebe-se então que a ucraneidade inscrita em alguns lugares de Curitiba ultrapassou as marcas de pertencimento especificamente étnico para espraiar-se em selo de identidade urbana, desde que estivesse circunscrito em espaços planejados. Importante é explorar então os modos como se expressavam o processo de evidenciação de identidades ucranianas que eram relevantes a alguns espaços geográficos, no município de Curitiba.

Na esteira do pensamento do sociólogo Walter Benjamin (1987, p. 26), nenhum rosto é tão surrealista quanto o rosto de uma cidade, justamente por condensar aspectos múltiplos em um só espaço. Curitiba não se tornou o lugar somente dos ucranianos, mas de tantas 
outras etnias (italianos, poloneses, árabes, japoneses, alemães) compondo um mosaico cultural diverso. Relevante é observar que por mais que a cidade agasalhe munícipes de tantas origens, espaços foram inspirados, pensados e construídos para serem referências de patrimônio cultural, o que poderia sugerir uma forma de fronteira. Contudo, em capitais metropolitanas, pensar em esquadrinhar e delimitar territórios onde é possível acomodar o que se julga específico é condenar-se à estigmatização e à marginalidade. Para além do conceito de ser a parte limítrofe de um espaço em relação a outro, as fronteiras circunscritas em espaços urbanos não podem ser concebidas por único viés: mais do que demarcações, são portas de passagem, pontos de transição e de intermediação.

Na cidade, as fronteiras são lugares onde o consentimento e a permissão andam par e passo. Por isso, conceber a fronteira somente pela ótica topográfica seria perder oportunidades de estudá-la como local por onde relações entre grupos são redesenhadas, reestruturadas, ou cristalizadas. Imperioso é observar que a luta pela preservação daquilo que se julga característico de um grupo ou as suas possíveis negociações e graus de tolerância se dão nas fronteiras. Logo, as fronteiras se tornam objeto de análises mais apuradas. É na fronteira que são estabelecidos e articulados os contatos, onde são celebrados acordos de interação e de relação entre os desiguais, regidos por regras de relacionamento, onde se observam critérios e sinais de identificação (BARTH, 1998, p.196).

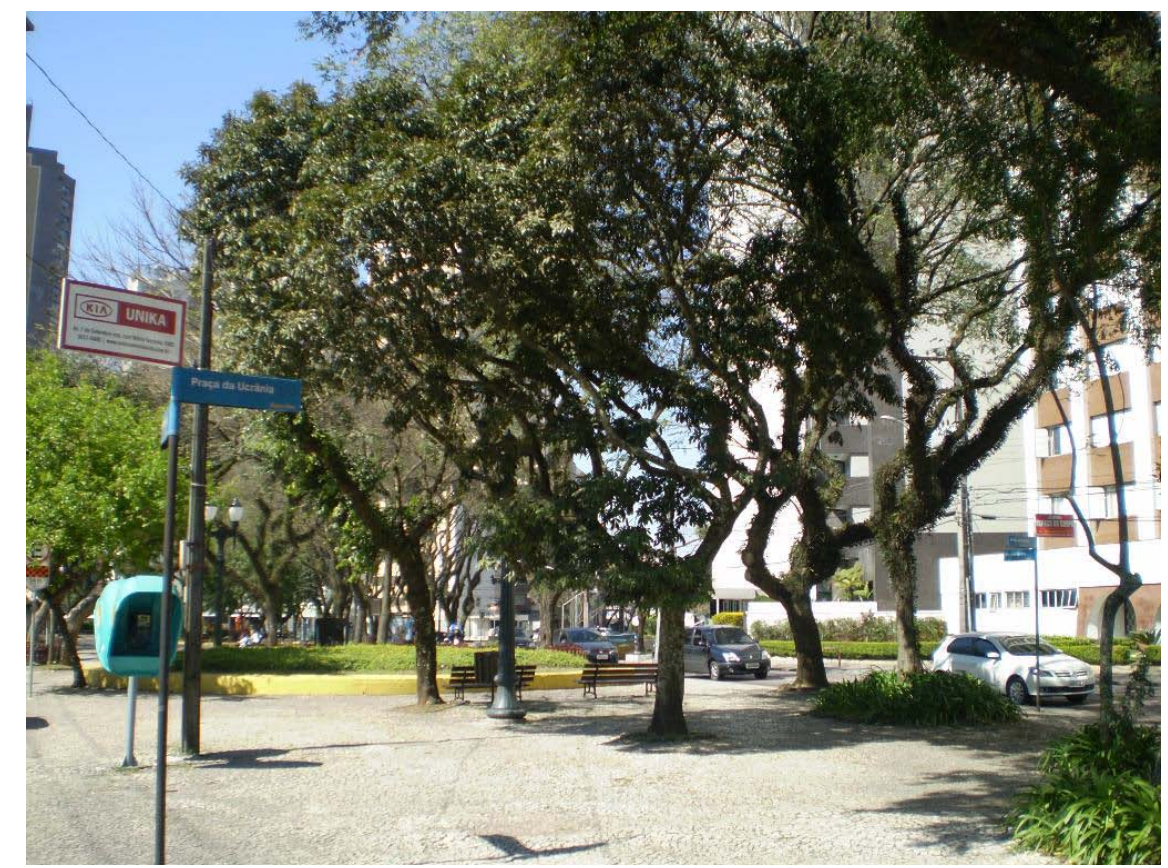

Figura 3 Praça do Ucranianos. Acervo da Prefeitura Municipal de Curitiba. Jan/2008

A construção da Praça dos Ucranianos, na década de 1980, no Bairro Bigorrilho, por exemplo, evidencia um esforço do poder público em marcar a presença daquela etnia na cidade; é o poder público que age na e sobre a cidade, mapeando e delimitando os espaços de 
identificação eslava. Contudo, observa-se que os contornos e a distribuição das peças que formam a praça (em torno da qual trafegam automóveis) pouco lembram o que um dia foi o bairro dos ucraínos. Remete, pelo contrário, não à especificidade, mas ao comum de todas as outras: árvores antigas repletas de parasitas e arbustos que brotam do chão empedernido, calçado por pedras coloridas, um orelhão, bancos improvisados para o descanso, luminárias e placas indicativas. No caso da dos ucranianos, a praça parece ser o ponto de convergência no qual se estabelece uma relação dialetizadora entre o cenário elucubrado de um passado e um sentido de contemporaneidade. Teoricamente ela é um lugar público pensado para o desempenho da vida urbana ao ar livre: lugar do ócio, da leitura, do refestelamento, da troca de ideias; dos encontros fortuitos e de enamoramentos, lugar de protesto e de contestação; lugar onde as feiras podem ser realizadas; lugar onde os músicos e demais artistas apresentam seus números gratuitamente.

Ao analisar a imagem acima, questiona-se ainda o que na praça há de específico da etnia ucraniana fora o próprio nome? Partindo do pressuposto que o que existe em um lugar tem razão de ser, depoimentos dos moradores locais informam que aos finais de semana, naquele lugar acontece a feira de produtos típicos: artesanato, culinária e peças de cama, mesa e banho com bordados ucranianos. Logo, a casualidade ou a benevolência são substituídas pela intenção.

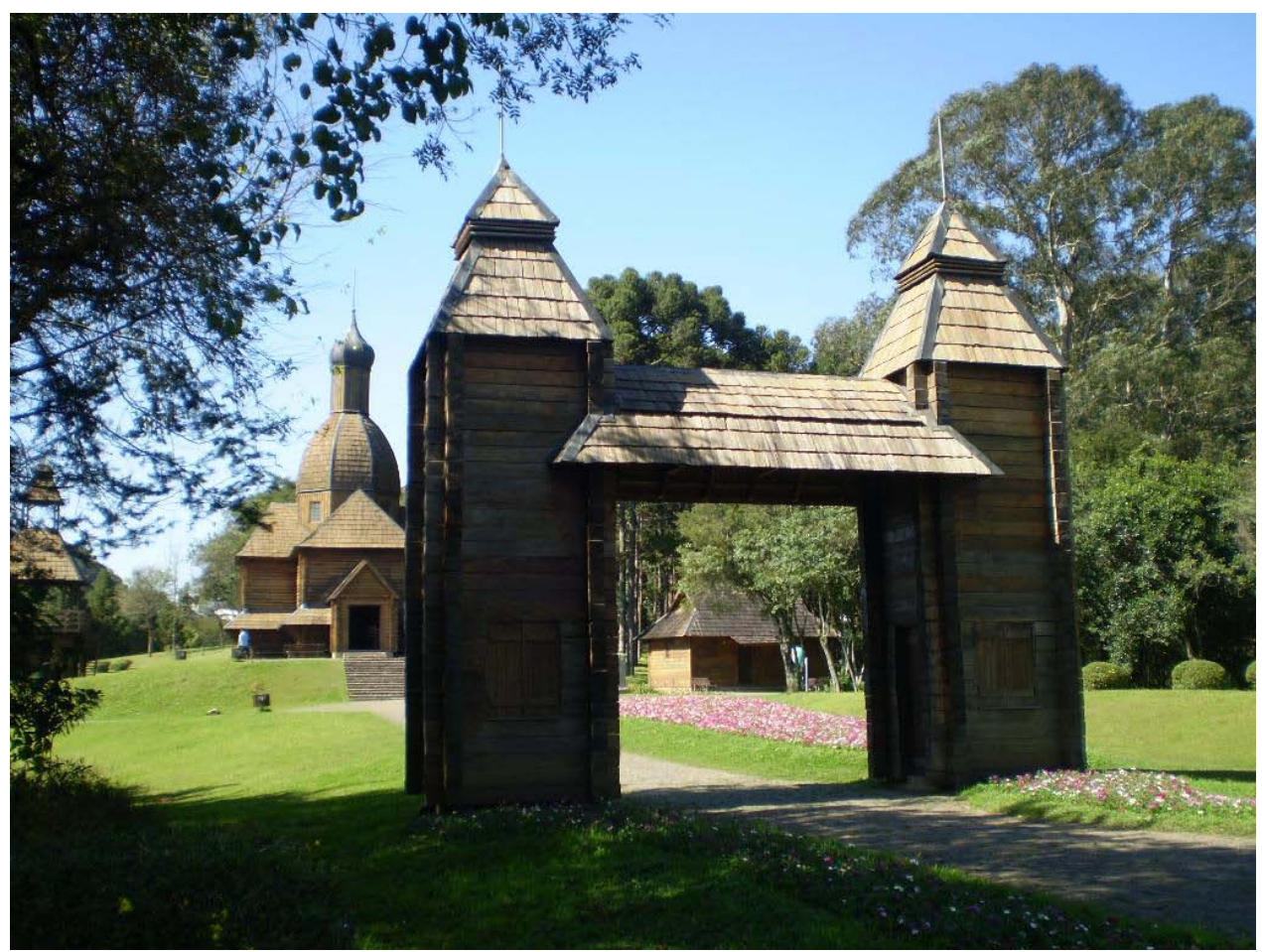

Figura 4 Memorial Ucraniano - Parque Tingui. Acervo da Prefeitura Municipal de Curitiba . Jan/2008. 
A imagem acima, contudo, certifica que a cultura ucraniana encravada na cidade de Curitiba tem seu lugar de distinção no Parque Tingui, cuja construção deu-se em 1995. Composto por uma réplica de uma igreja com características bizantino-eslavas, em homenagem a São Miguel Arcanjo, por uma casa e um portal - todos em madeira encaixada, não fazendo uso de um prego sequer -, o Memorial Ucraniano, circunscrito em meio à natureza, tornou-se ponto turístico da capital do Paraná, desde que foi construído no contexto das comemorações do centenário da chegada dos imigrantes à cidade. Se "a cidade é um fenômeno que se revela pela percepção de emoções e sentimentos dados pelo viver urbano” (PESAVENTO, 2007, p.12), a ucraneidade encenada nesses espaços informa que Curitiba tolerou não só os imigrantes do leste europeu, como aderiu às invencionices étnicas. Segundo Eric Hobsbawm (1984, p.10) e Anthony Giddens (2005, p.50-54) as tradições são inventadas objetivando interesses que oscilam da espetacularização teatral à comercialização da herança.

Se o meio rural, por certo, aparece como o locus privilegiado de manutenção da cultura e costumes étnicos, onde praticamente a possibilidade de fazer negociações para lograr certa interação era mínima, em Curitiba com a edificação dos lugares de memória, percebe-se que se tentou trazer o campo para o espaço urbano, dando-lhe enobrecimento. Desta forma, a cidade se abre às paisagens protocolarmente elaboradas com a invenção de espaços distintos, onde o culto à cultura se equipara ao culto à natureza.

O Parque Tingui e a Praça dos Ucranianos podem ser considerados lugares de cruzamento de correntes diversas cuja materialidade cultural se acomoda na dinâmica das relações das quais se serve para existir. Ao se impingir marcas de identificação étnica na cidade corre-se o risco de se propagar a necessidade da existência de territórios exclusivos aos diferentes. Tal pensamento é pulverizado pela própria urbanidade, que essencialmente é capaz de aliançar práticas culturais dessemelhantes desbancando toda e qualquer forma cativa de se viver em separado. Isto porque, diferentemente do que ocorre em meios rurais onde a demarcação de linhas imaginárias restringe a circulação, troca e interação da cultura entre outros campos de encenação cultural, em espaços urbanos parece que as fronteiras são muito líquidas, porosas e pouco funcionais.

Se a imigração não pode ser vista apenas como mero deslocamento de pessoas, mas também como deslocamento da cultura e do simbólico, é em territórios específicos ou não que tal cultura se materializa.

A cidade não tem compromisso com nenhuma etnia especifica, pois abarca todas. Logo, a materialidade cultural torna-se patrimônio não mais exclusivo de uma grupo, mas de toda a urbe. Em espaços urbanos não se apaga o específico de um grupo, justamente porque 
se realoca a outros planos ou a outros graus de importância (AUGÉ, 1994, p.72). Nota-se aqui que a crença de que um grupo de pessoas possa ser o único guardião de valores culturais seus é atenuada quando se transferem estas responsabilidades ao poder público.

Se os ucranianos atuam nos cenários da cidade, mesmo que coadjuvando, emprestando-lhe plasticidade, movimento e som, observa-se que a materialidade cultural de um grupo pode ser expressa sob diversas formas e é reeditada e reinventada tantas vezes quanto for possível transpor, individual ou coletivamente, aspectos importantes do que se julga importante para uma família, um grupo, uma comunidade, uma etnia.

\title{
AMIDST GLASS-WALLED BUILDINGS, A SLAVIC CROSS: Ukrainians, cultural assets and the city
}

\begin{abstract}
The purpose of this article is to comment on the venue where Orthodox Ukrainian immigrants settled in the city of Curitiba and to verify strategies adopted in order to preserve ethnic cultural assets during the urbanization of Avenue Candido Hartmann (called the Ukraine Village until 1978). The study of cultural assets and the city is supported by interviews given by immigrants that used to live in the neighborhood, highlighting the dialectic relationship between the venue and the beliefs and cultural practices of this group. If on the one hand urbanity tends to homogenize venues created for a specific purpose, on the other it strengthens ethnic identification in dedicated venues when there is an interest.
\end{abstract}

Key words: Orthodox Church, cultural assets; city.

\section{Referências}

ANDREAZZA, M. L. Uma herança camponesa: moradia e transmissão patrimonial entre imigrantes ucranianos (Brasil, 1895-1995), Nuevo Mundo Mundos Nuevos. Colóquios, 2008.

ANSAY, Pierre. Pensar a cidade. Textos escolhidos. Bruxelas. AAM Editoras, 1989.

AUGÉ, Marc. Não-lugares: introdução a uma antropologia da supermodernidade. Campinas SP: Papirus, 1994.

BARTH, Fredrik. Grupos étnicos e suas fronteiras. In.: POUTIGNAT, Philippe e STREIFFFNART, Jocelyne. Teorias da etnicidade. São Paulo: UNESP, 1998.

BAUDELAIRE, Charles. Sobre a modernidade. Rio de Janeiro: Paz e Terra, 2007.

BENJAMIN, Walter. Magia e técnica, arte e política. Ensaios sobre literatura e história da cultura. São Paulo: Editora Brasiliense, 1987. 
BENJAMIN, Walter. Paris, capital do século XIX. In: KOTHE, Flávio R. (org). Sociologia. São Paulo. Ática, 1985.

CALVINO, Ítalo. As cidades invisíveis. São Paulo: Companhia das Letras, 1990.

CANCLINI, Néstor Garcia. Culturas híbridas: estratégias para entrar e sair da modernidade. São Paulo: Editora da Universidade de São Paulo, 2008.

CZAIKOWSKI, Mariano. Os Ucranianos no Brasil. In: Jornal o Lavrador, Curitiba, $n^{\circ} 433$, Jan/2011, p 12-14.

GIDDENS, Anthony. Mundo em descontrole: o que a globalização está fazendo de nós. Rio de Janeiro: Record, 2005.

HOBSBAWM, Eric; RANGER, Terence (Orgs.). A invenção das tradições. Rio de Janeiro: Paz e Terra, 1984.

LACERDA, Dulcídio T. de. A Colonização e o Cultivo de Trigo no Terceiro Planalto. In: Diário da Tarde. Curitiba: 12 de abril de 1951, p. 02

PESAVENTO, Sandra Jatahy. Cidades visíveis, cidades sensíveis, cidades imaginárias. Revista Brasileira de História, São Paulo, v. 27, n. 53, p. 11-23, 2007, p. 12.

PESAVENTO, Sandra Jatahy. Muito além do espaço: por uma história cultural do urbano. Estudos Históricos, Rio de Janeiro, v. 8, n. 16, p. 279-290, 1995. p. 280.

PESAVENTO, Sandra Jathay. O imaginário da cidade: versões literárias do urbano. Porto Alegre: Editora da UFRGS, 1999.

SANTOS, Milton. Por uma outra globalização: do pensamento único à consciência universal. Rio de Janeiro: Record, 2000.

SEYFERTH, Giralda. Imigração e cultura no Brasil. Brasília: Editora Universidade de Brasília, 1990.

THOMPSON, Paul. A voz do passado: história oral. Rio de Janeiro: Paz e Terra, 1992. 